\title{
Executive Development for Professionals in A Family Company
}

\author{
Vidi Rosen $^{1}$, Muchlis R. Luddin² and Yetti Supriyati ${ }^{3}$ \\ \{vidi.rosen@amg.co.id ${ }^{1}$, muchlis-rantoni@unj.ac.id ${ }^{2}, \&$ yetti.supriyati@unj.ac.id ${ }^{3}$ \} \\ ${ }^{1,2,3}$ Universitas Negeri Jakarta, Indonesia
}

\begin{abstract}
Family companies usually start from small companies, they grow and become large and even become conglomerate companies. When the company gets bigger it must involve outside executives to be able to help manage the company. On the other hand, being an executive of a family company is not an easy task considering a company will depend on culture developed by the founder, especially family members who are still active in the company. This research aimed to find what kind of development program that the company should have to make the company able to supply the needs of executives. This research used the single instrument case study that started by interviewing the family and key people in the company and followed by observation, literature studies that related to suitable theory or cases. As a result, this research found how a family business should conduct the structure executive development programs that can fulfil the needs of business leader without neglecting the values and cultures that the founder established. As the implication by implementing this kind of executive development programs, a family business can expand their business because they can supply executives that can help the family to run the company.
\end{abstract}

Keywords: Executive Development, Succession Planning, People Development

\section{INTRODUCTION}

The contribution of family companies in many countries is very significant in the economy [1]. In Indonesia, PT Bakrie and Brothers Tbk (BB) is known as one of the oldest family companies that still exists and operates in Indonesia. Family companies usually started small, over time they grow and become large and even become conglomerate companies, making it difficult to be managed by family members [2]. BB as a conglomerate company cannot be managed solely by the Bakrie family, because the number of existing family members is not comparable to the needs of executives so it must involve professional executives from outside the family. Ensuring the company to always have executives to fill important positions is a difficult challenge [3], [4]. For this reason, the company must do something to ensure that the company has enough executives. [5], [6]. Retirement and executive turnover in important positions always bring problems for the company, therefore the company must have succession planning programs and consistently develop their executives. Succession planning is a process that takes place continuously, which systematically identifies, evaluates, and develops 
capabilities in leading organizations or companies with the aim of always improving company performance [7], [8]. Dahlke stated that the succession process was needed to ensure the readiness of the company to be able to replace employees who left key positions within the company with quality replacements. [9]. As a consequence, companies must always develop their executives through executive programs (executive development) and training to ensure executives owned are always developing and ready if needed [10], [11]. Training is an important thing that is very important in an effort to improve the ability of executives in a company [12]. Succession planning and executive development are two things that cannot be separated and must go together. Management of family companies is different from management in ordinary commercial companies because of family members involved in managing the company [13]. The tastes and individual character of the founder, family members and executives involved in managing the company color the interactions that occur within them. Executives who are in a family company must be able to adjust to the desires and culture formed by family members [2]. So, the development of executives in the company things as mentioned above become something important to be addressed [14], [15]. Inside BB itself there are several programs that aim to develop corporate executives at various levels but not all programs can run smoothly, and many obstacles are faced. On the other hand, BB proves that in the age of more than 75 years the company can still fulfill its needs for tough executives and can lead the company.

In the initial research that was conducted, it was found that twenty percent of the employees working at BB were over forty-five years old. This is in line with the age of the company which is seventy-five years old. In the near future there will be many employees who will enter the retirement age, and some of them are in a strategic position.

BB faces the challenge of preparing a replacement for employees who will retire or go looking for opportunities outside the company. The number of subsidiaries owned by BB also causes demands to prepare corporate leaders at various levels to be even higher. This is complicated by the variety of businesses they have. The important thing to be investigated is how BB develops its executives to always be available in accordance with the amount needed by the company so that the company's business can continue and always develop.

\section{METHOD}

The research begins by looking at what problems will be examined which consist of what is expected to occur according to what should be running in the executive development program at $\mathrm{BB}$ as a family company based on existing theories and references (ideal conditions). This is then compared to the reality that occurs in the process of executive development which may conflict with the literature or cases that have happened before. This research concludes with conclusions formed by researchers about the overall meaning obtained from the case. This research is a single instrument case study because researchers focus on issues or problems then choose a limited case to illustrate this problem [16], [17].

The study continued with initial observation by observing the ongoing process directly by conducting interviews. Then proceed with conducting literature studies through articles and books related to theory or cases regarding executive development. From the information obtained, the formulation of the problem consists of a process of succession management and executive development, and the focus and sub-focus of the research or parts of which the researcher will focus on are examined and interesting to study. Also determined what data needs to be taken, where this data will be obtained. Organizing data by conducting transcripts of interview results, reducing data by coding / coding to clarify the respondent's answers from the 
in-depth interview process and produce researchers' findings. For the validity of interview data and other researcher's triangulation of data sources..

\section{RESULT AND DISCUSSION}

\subsection{Development of Leader Competence}

In developing the executive program, the first thing to do by BB is to determine what competencies were needed and wanted to be developed for the executives they had. Competence is the basis and key for executive development in the company [18]. BB realizes that increasing competence is one of the keys to business success, so BB composes a matrix and dictionary of competencies that are used as the basis for selection and development for leaders in the company environment. The matrix is called Bakrie Leadership Competency Matrix (BLCM). BLCM is used to design a comprehensive executive development program, starting from the recruitment process to the preparation of training packages in developing existing executives. This matrix is derived from the vision, mission, value of the company, the culture of the company, direction from the Bakrie family, and also the company's development plan in the future. Unlike many other family companies that have not yet reached this stage and are still busy thinking about succession within their families, BB has thought about what type of executive is needed to help the Bakrie family build their company

\subsection{System and Infrastructure Development}

BB's HR development program is implemented through various HR and organizational management program initiatives directed towards accelerating the achievement of business strategies and targets. Making and developing programs is one of the keys to the success of executive development in a company [19]. The program developed is not only training but must be carried out thoroughly and integrated [20]. Some program initiatives carried out include review of organizational design development in accordance with business models, HR planning and recruitment programs, performance management, compensation management, HR systems and procedures, leadership development patterns and programs to develop corporate culture into programs created and implemented in BB. It is expected that the output of this process will be the creation of natural executives who are capable of becoming talent in the future.

The responsibility for implementing company resource development and preparing future leaders is given to the Bakrie Learning Center (BLC), which is an independent unit that is based on $\mathrm{BB}$ and coordinates the development program in the BB business unit. The daily management of human resources is handed over to each unit but related to the development of leadership and macro strategies, BLC has the role of providing direction and coordinating the related program programs.

Through BLC the Company develops a Talent Management system in order to ensure longterm leadership sustainability in line with the Company's business. Broadly speaking, the talent management system includes (1) the process of talent assessment and identification (talent assessment and identification), with this, BLC prepares standards for the recruitment process, test tools that can be used, and coordinates its implementation for program programs that are between units and apply uniformly throughout BB, (2) Implementation of the regeneration system of Bakrie Succession Plan, BLC facilitates development program programs, implementation of selection, assessment, assignments, and placement of executives that are cross units, (3) Development of talent leadership programs through Bakrie Leadership Development Program, BLC developed syllabus, training material, implementation, and program evaluation carried out, (4) Formulated and disseminated Bakrie values (Trimatra Bakrie), BLC was tasked with developing socialization materials, e-learning materials, 
integrating the Bakrie Trimatra the training program that already exists, and other activities related to the dissemination of corporate culture, and (5) Running the Bakrie Engineering Program.

The Bakrie Learning Center is also responsible for implementing the Human Asset Value Mapping program which aims to measure the competence of executives in business units on a regular basis and report it to the Board of Directors to determine their readiness and compatibility with the competencies needed in managing the company.

From what was stated above, it can be seen that BB is seriously and systematically trying to prepare prospective executive candidates in the future by making a system and infrastructure in the form of units that are indeed responsible for ensuring the creation of executives for the company in the future.

\subsection{Executive Development Program}

For non-family executives, BB has BLCM that explains the competencies needed by each executive in order to succeed in their respective fields of business. This is derived from the value of the Trimatra Bakrie, vision, mission, and direction from the Bakrie family.

The matrix also has developed a leadership development program, namely programs that are made to be able to support executives from various levels in order to develop themselves so they can become successful leaders in BB. The executive development program refers to the Bakrie Leadership Competency Matrix (BLCM). This development program is called the Bakrie Leadership Journey, which is the details of programs that must be followed by each level of management.

In terms of implementation BB commissioned BLC, whose task is to develop and coordinate programs and implement the existing development environment $\mathrm{BB}$. BLC has the role of $\mathrm{BB}$ (Holding) to play a role in ensuring that the supply of the number of prospective leaders is sufficient and there is every level with the hope that they can be projected to be able to position strategic positions within the company. This is done to prepare executives from supervisors, managers, General Managers and Vice Presidents to become executives.

Executive supply is obtained from a process called human asset value mapping. Each business unit in the $\mathrm{BB}$ area conducts a human asset value mapping annually where existing executives are assessed based on their performance and competencies, the results of which are used to project the development of executives in the future. Executives who have performance and competencies that are in accordance with the BLC are then recruited, fostered and included in programs in the Bakrie Leadership Journey in the hope that these executives can develop in various businesses from supervisors to senior executives.

One interesting finding is the application of culture and corporate values developed by the Bakrie family which refers to expected behavior. This can be seen from the training material and criteria for the assessment criteria that are in the program. This makes all executives participating in the development program understand and adjust to what the company expects. Of course, it will be different if the company recruits executives who have been made from outside the company, an understanding of the values and corporate culture will not be owned by them.

For non-families, the selection of executive candidates is carried out in each part of the business unit. Selection is based on performance, competence and behavior. The behavior here means behavior that is in accordance with the culture of the company. The selected people will be sent to the holding and entered into the Bakrie Learning Center which coordinates executive development programs. BLC will be tasked with implementing the development of prospective leaders at each level, in the form of training, coaching, mentoring, seminars, and others. The 
track record of each prospective leader is kept and managed, the data is useful to make decisions about who will become the company's leader if there is a business unit that needs it. What programs should be done from each level of management can be seen in the Bakrie Leadership Journey attachment. The Bakrie Learning Center is a unit called Bakrie Strategic Solution (BSS). BSS is responsible together with BLC to carry out activities related to development and assistance within the group. Education in BLC range in tier from Supervisor, Manager, General Manager, Vice President to Executive program.

When a program has been determined that must be followed in accordance with their Bakrie Leadership Journey, it must be related to BLC, which is quite intense, meaning that in addition to the program in class they also have to take part in online development programs. After the class and online program is completed, they are required to take an online test that is knowledgeable in nature and there is a minimum number that must be achieved in order to graduate. If they don't pass, they can't / are difficult to get a promotion. In addition to online tests related to management's knowledge and expertise, they are required to make projects related to the work that will be implemented. The objective of the project is to increase the business where they are. The project time ranges from 3-6 months and each month they have to report progress from the project to BLC. When the project is complete, they must present the results of the project before the Board of Management. The board decides whether they succeed or not.

There are two assessments, namely tests related to knowledge and from project implementation. The form of the project is different for each level. If the level supervisor, the project is only related to day-to-day work, while the level Manager must be a project that is related to other departments, while the Senior Manager level up to VP in the form of projects that solve problems in the company and business analysis of a business and Executive level create new complete proposal form until implementation.

The control process is carried out after they implemented the project implementation. Control is carried out by the BNNR Board of Directors by conducting regular evaluations of assignments for three or six months. If the development of the project is not as expected, the BOD will provide input on improvements so that the project can run well. During this period BOD observes and assesses the ability and suitability of prospective successors with jobs and companies. If the candidate feels that it is not right then it can be decided not to continue the succession program. If they get away from the program which is followed indirectly by promotion but still monitored the performance. Besides that, the Human Asset Value Mapping process continues to be carried out as a means of control and evaluation of executive and executive development in business units. This is done to ensure that executive supply can continue to occur with the discovery of new executives in the business units while continuing to monitor existing candidates. If indeed a further development program is needed for existing successors, BLC will make and implement the development program. 


\begin{tabular}{|c|c|c|}
\hline $\begin{array}{l}\text { Preparation of the } \\
\text { Basic Competency } \\
\text { Matrix }\end{array}$ & $\begin{array}{l}\text { System and } \\
\text { Infrastructure } \\
\text { Development }\end{array}$ & $\begin{array}{l}\text { Executive } \\
\text { Development } \\
\text { Program }\end{array}$ \\
\hline $\begin{array}{l}\text { - Bakrie Leadership } \\
\text { Competency } \\
\text { Matrix (BLCM) }\end{array}$ & $\begin{array}{l}\text { Development of } \\
\text { human resource } \\
\text { systems based on } \\
\text { BLCM } \\
\text { Established Bakrie } \\
\text { Learning Center as } \\
\text { the intitution in } \\
\text { charge }\end{array}$ & $\begin{array}{l}\square \text { Talent } \\
\text { Management } \\
\square \text { Bakrie Leadership } \\
\text { Journey }\end{array}$ \\
\hline
\end{tabular}

Figure 1: Executive Development Program in PT Bakrie Brothers Tbk

\section{CONCLUSION}

Based on the findings and discussion, the researcher can draw some conclusions related to Executive Development at BB. It was realized that the success of the succession process depends on the quality of the preparation, for that there is a need for a leadership development mechanism that prepares leaders in the BB. Executive development starts from the preparation of the leadership competency matrix as the basis for developing development programs. This is followed by the development of the system and infrastructure needed to ensure that there are parts within the company that regulate and manage executive development programs. This was ended with an executive development program that was integrated with programs within the company. What should not be forgotten is that as a family company, the values and things that are considered important must be accommodated and reflected in the program developed.

\section{REFERENCE}

[1] A. K. Mishra, H. S. El-Osta, and S. Shaik, "Succession decisions in U.S. family farm businesses," J. Agric. Resour. Econ., vol. 35, no. 1, pp. 133-152, 2010.

[2] S. Klein and F.-A. Bell, "Non-family Executives in Family Businesses: a Literature Review," Electonic J. Fam. Bus. Stud., vol. 1, no. 1, pp. 19-37, 2007.

[3] M. L. Litano and D. A. Major, "Facilitating a Whole-Life Approach to Career Development," J. Career Dev., vol. 43, no. 1, pp. 52-65, 2015.

[4] M. M. Varhegyi and D. M. Jepsen, "Director succession planning in not-for-profit boards," Asia Pacific J. Hum. Resour., vol. 55, no. 1, pp. 106-126, 2017.

[5] E. Estedadi, "The importance of succession planning in organizations," $A d v$. Soc. Humanit. Manag., vol. 2, no. 3, pp. 41-47, 2015.

[6] Ali Akbar Ahmadi, Freyedon Ahmadi, and Javad Abbaspalangi, "Talent management and succession planning,” Interdiscip. J. Contemp. Res. Bus., vol. 4, no. 1, pp. 213-224, 2012.

[7] Gary Dessler, Human Resources Management. New Jersey: Pearson Prentice Hall, 2008.

[8] M. Mokhber et al., "Succession Planning and Family Business Performance in SMEs," $J$. Manag. Dev., vol. 36, no. 3, pp. 2-27, 2017.

[9] Anrie Dahlke, Business Succession Planning For Dummies. Hoboken: Wiley, 2012.

[10] N. Calvo Babío and R. García Rodríguez, "Talent management in professional services 
firms: a HR issue?," Int. J. Organ. Anal., vol. 18, no. 4, pp. 392-411, 2010.

[11] Q. Spitzer and R. Evans, "How to succeed at executive succession," Lead. to Lead., vol. 1998, no. 10, pp. 47-53, 1998.

[12] S. Liff and P. Gustavson, "Designed for Success: How Building a Team of Leaders Transformed a Company," Glob. Bus. Organ. Excell., vol. 35, no. 4, pp. 17-27, 2016.

[13] K. Mooris and Marry Barret, Learning Family Business, Paradoxis, Pathways. Hampsire: Ashgate Publishing Limted, 2002.

[14] A. Surdej and K. Wach, Succession Choices in Family Firms. The Case of Poland. Krakow: Adam Marszałek, 2010.

[15] R. Barnett and S. Davis, "Creating Greater Success in Succession Planning," Adv. Dev. Hum. Resour., vol. 10, no. 5, pp. 721-739, 2008.

[16] J. W. Creswell, Qualitative Inquiry and Research Design. Thousand Oak: Sage Publications, 2006.

[17] J. W. Creswell, Qualitative Inquiry and Research Design - Choosing among Five Traditions. United Kingdom: Sage Publications, 2007.

[18] John R Schultz, "The Elements of Leadership," Glob. Bus. Organ. Excell., vol. 32, no. 6, pp. 47-54, 2015.

[19] W. F. Cascio, "Human Resource Management Review Training trends : Macro, micro , and policy issues," Hum. Resour. Manag. Rev., no. November, pp. 0-1, 2017.

[20] G. Chen and R. J. Klimoski, "Training and development of human resources at work: Is the state of our science strong?," Hum. Resour. Manag. Rev., vol. 17, no. 2, pp. 180-190, 2007. 